\title{
ПСИХОЛОГІЧНІ ОСОБЛИВОСТІ СПРИЙНЯТТЯ КРЕДИТНИХ ПРОДУКТІВ ЗДОБУВАЧАМИ ВИЩОЇ ОСВІТИ
}

\author{
Світлана Шевченко \\ кандидат психологічних наук, доцент, доцент кафедри психології \\ Мелітопольський державний педагогічний університет імені Богдана Хмельницького \\ 72300, Україна, м. Мелітополь, вул. Гетьманська, 20 \\ $\underline{\text { Svetlanashev1986@gmail.com, https://orcid.org/0000-0001-8281-243X }}$

\section{Ганна Варіна} \\ магістр психології, старший викладач кафедри психології \\ Мелітопольський державний педагогічний університет імені Богдана Хмельницького \\ 72300, Україна, м. Мелітополь, вул. Гетьманська, 20 \\ anyavarina22@gmail.com, https://orcid.org/0000-0002-0087-4264
}

\begin{abstract}
Анотація
Вивчення зумовленості сприйняття особистістю грошей, кредитних продуктів виявляється все більш затребуваним проблемним полем досліджень, про що свідчать новітні публікації як західних, так і українських вчених. Проте у більшості досліджень вивчаються лише окремі передумови особистісного сприйняття грошей та кредитів. Мета дослідження - емпіричне вивчення психологічних особливостей сприйняття кредитних продуктів банківських установ здобувачами вищої освіти. Виходячи з мети, завданнями дослідження були такі: визначення типів грошових настановлень у здобувачів, вивчення чинників, які впливають на ставлення здобувачів вищої освіти до грошей, визначення обізнаності здобувачів у питаннях діяльності банківських установ, поведінки користувачів банківських кредитів і доцільності користування кредитними послугами банків. Нами було використано такі методики: методики «Шкала грошових уявлень та поведінки» (Money Beliefand Behaviour Scale) (авт. А. Фернем), анкета О.Г. Ходакевич «Моє ставлення до грошей», опитувальник «Ставлення до горошей та кредиту здобувачів вищої освіти» (авт. С.В. Шевченко), методика «Шкала грошових уявлень та поведінки» (А. Фермен, модифікація М.В. Сімків). Визначено, що в юнацькому віці своєрідно виявляється система базисних ставлень до грошей: у ставленні до себе збільшується ступінь адекватності сприйняття кредитів, водночас оцінка кредитних продуктів здійснюється на основі власних уявлень, які подекуди бувають ілюзорними і поверхневими, зростає ступінь довіри до банківських установ, а власний образ грошей і кредиту менше залежить від оцінок інших. Водночас ускладнення перебігу процесу економічної соціалізації підростаючого покоління нерідко призводить до виникнення неконструктивного сприйняття грошей і кредитів: від надання їм дуже великого значення, бажання збагатитися будь-яким шляхом (аж до незаконних дій) до повного нівелювання їх значення.
\end{abstract}

Ключові слова: кредитні продукти, гроші, ставлення до грошей, сприйняття кредитів, грошові настановлення, здобувачі вищої освіти. 


\section{Вступ}

Вивчення психологічних особливостей сприйняття грошей i кредитних продуктів здобувачами вищої освіти є вкрай актуальною проблемою, оскільки це питання тривалий час було предметом вивчення лише у межах економічних наук, зважаючи на те, що гроші й кредитні продукти $є$ неодмінними атрибутами економічного життя і їх сприйняття $\epsilon$ цілком раціональним. Проте, як свідчать численні публікації, є велика кількість феноменів щодо сприйняття кредитних продуктів, які неможливо пояснити лише з економічно-раціональної точки зору. Вони можуть бути осмислені в психологічній науці, яка має своє розуміння раціональності людини. Вивчення зумовленості сприйняття особистістю грошей, кредитних продуктів виявляється все більш затребуваним проблемним полем досліджень, про що свідчать нові публікації як західних, так і українських вчених. Проте в більшості досліджень вивчаються лише окремі передумови особистісного сприйняття грошей і кредитів. Особливо актуальним вбачається вивчення специфіки сприйняття кредитних продуктів особистістю юнацького віку. В юності своєрідно виявляється система базисних ставлень до грошей: у ставленні до себе збільшується ступінь адекватності сприйняття кредитів, водночас оцінка кредитних продуктів здійснюється на основі особистих уявлень, які подекуди бувають ілюзорними та поверхневими, зростає рівень довіри до банківських установ, а власний образ грошей й кредиту менше залежить від оцінок інших. Зіткнувшись 3 реаліями сучасного життя, в сучасних здобувачів вищої освіти формується оманний образ «успішна людина фінансова незалежна людина», самоствердження в сучасну ринково-економічну епоху господарювання неможливе без прагнення особистості бути суб'єктом економічного життя суспільства. Водночас ускладнення перебігу процесу економічної соціалізації підростаючого покоління нерідко призводить до появи неконструктивного сприйняття грошей і кредитів: від надання їм великого значення, бажання збагатитися будь-яким шляхом (і навіть незаконними діями) до повного нівелювання їх значення. Саме тому важливим $\epsilon$ визначення особливостей сприйняття кредитних продуктів банківських установ здобувачами вищої освіти. В психологічній науці це питання ще не набуло належної розробки.

3-поміж зарубіжних емпіричних досліджень, спрямованих на визначення загальних понять «кредитних продуктів» і впливу засобів реклами на поширення споживчих потреб молоді, привертає інтерес дослідження F. Fan, K. Chan (Fan \& Chan, 2019). Автори вивчають вплив реклами на прийняття рішення молодими споживачами щодо отримання грошових позик. У дослідженні презентовано методи опитування щодо аналізу сприйняття оголошень про грошові позики за демографічними ознаками населення. Зважаючи на те, що фінансові продукти і послуги все частіше присутні в нашому повсякденному житті, дуже важливо знати переваги і можливості, які можна отримати, використовуючи їх. Отже, ряд досліджень орієнтований на визначення існування базової структури, яка пояснює знання за темами доходів, управління капіталом, заощаджень та інвестицій, витрат і кредитних можливостей у житті студентів закладів вищої освіти (Larracilla-Salazar, Peña-Osorio \& Molchanova, 2019).

B епоху інформаційного прогресу i діджиталізації, переходу маркетингових технологій в електронні ресурси та соціальні мережі виникають нові проблеми, пов'язані 3 впливом розповсюджених блогів і соціальних мереж на прийняття молоддю фінансових рішень. Науковці аналізують можливості й користь соціальних мереж в прийнятті фінансових рішень серед різних однорідних груп на основі демографічних даних в розвинутих європейських країнах (Khan, Akhtar \& Tripathi, 2020). За результатами технічного й інформаційного прогресу помітний розширений перехід валютної системи в інформаційну, 
що сприяє широкому розповсюдженню електронних грошей і платіжних кредитних карт, які найбільш активно застосовує молодь. Використання електронних кредитних продуктів відіграє, на думку авторів важливу посередницьку роль, адже всі фінансові конструкції відбивають позитивний вплив на фінансове задоволення від застосування EPS. Акцентуючи увагу на збільшення відсоткового використання кредитних продуктів саме молоддю, дослідники виявили, що поступове збільшення рівня наявного доходу і зайнятості в студентському середовищі пов'язано з більшою безвідповідальністю застосування кредитних карт. Вищий рівень наявного доходу був пов'язаний з більшою кількістю нав'язливих покупок i занепокоєнням, пов'язаним 3 грошовою стабільністю. Неповна зайнятість студентів була пов'язана 3 найбільшим рівнем чутливості до цінової політики. Автори наголошують на необхідності розвитку фінансової грамотності шляхом розробки системи консультування молоді з питань про використання кредитної картки і належне управління особистими фінансами (Fogel \& Schneider, 2011). Також в лонгітюдному емпіричному дослідженні науковці доводять, що фінансові можливості, фінансові поради, фінансове занепокоєння i використання EPS мають прямий позитивний вплив на фінансове задоволення людини. Використання EPS відіграє важливу посередницьку роль, оскільки всі фінансові конструкції відбивають позитивний вплив на фінансове задоволення від використання EPS. Ці результати є важливим науковим внеском, адже вони розкривають розуміння детермінант фінансового задоволення в контексті країни, що розвивається 3 низьким рівнем доходу, а також життєво важливу роль використання EPS для фінансового задоволення людини в сьогоднішню епоху цифрових технологій (Khan \& Akhtar, 2020).

Враховуючи бурхливий економічний та інформаційний розвиток сучасних суспільних стосунків і розширенні можливостей у отриманні й використанні кредитних продуктів, науковці наголошують на визначенні пріоритетних можливостей та шляхів розширення фінансових прав і можливостей у молодіжному середовищі (Luukkanen \& Uusitalo, 2019), та формування фінансової грамотності, яка розглядається авторами у двофакторній площині: перша, пов'язана зі знаннями та компетентностями, щодо використання і застосування кредитних коштів молодими людьми для заощаджень та інвестицій, а друга - зі знаннями щодо використання і застосуванням в галузі управління капіталом фінансовим і людським. Фінансові можливості можуть бути поліпшені завдяки розширенню фінансових знань людей, їх фінансової поведінки та сприяння їх залученню до фінансові послуги. Крім того, непрямий вплив фінансових знань і стосунки на фінансові можливості виявляється значним, що підкреслює важливість формування відповідальної фінансової поведінки (Çera, Khan, Mlouk \& Brabenec, 2020). Досліджуючи вплив маркетингових стратегій кредитних провайдерів на розповсюдження кредитних продуктів серед молоді, науковці наголошують на важливості клієнтцентрованого підходу та аналізу соціальних запитів щодо кредитних продуктів, ціноутворення та акцій. Дослідження засвідчило, що товар, стратегії ціноутворення та доступність кредитних продуктів безпосередньо впливають на використання молоддю кредитних карт (Kassim \& Hussin, 2016).

В контексті дослідження психологічного конструкту сприйняття та використання кредитних продуктів дослідники акцентують увагу на тому, що хоча й існують шкали, спрямовані на оцінку сприйняття грошей як валютних продуктів, водночас жодна 3 них не враховує ментальні і емоційні переживання, які породжує використання кредитних продуктів людьми у повсякденному житті. Автори пояснюють, що сенсорні асоціації зі способами оплати породжують різну когнітивну і емоційну чутливість в уявних звітах і впливають на 
тип, цінність і кількість використаних кредитних коштів. Незважаючи на те, що все більше уваги надається впливу режиму оплати на поведінку щодо витрат, було докладено немало зусиль для розробки відповідної шкали вимірювання, щоб зафіксувати когнітивні й емоційні асоціації споживачів, пов'язані з режимами оплати. Відповідно, дослідники обгрунтовують використання розробленої концептуальної шкали, яка відбиває сприйняття особистістю способів оплати при використанні кредитних продуктів. Шкала складається з 19 пунктів і презентує чотири виміри: емоції, які стосуються способів оплати готівкою і картками, соціальне й особисте задоволення, управління грошима. Шкала вимірювання РРМ демонструє прийнятну надійність і засвідчує, що сприйняття споживачами способів оплати впливає на поведінку щодо витрат і пророкує володіння особистістю фінансовими картами. Шкала корисна для розуміння когнітивних і емоційних асоціацій споживачів 3 різними способами оплати, особливо 3 використанням «власних грошей» і того, як ці асоціації впливають на вибір способу оплати та кількість використаних кредитних продуктів (Khan, Belk \& Craig-Lees, 2015).

Отже, більшість зарубіжних досліджень присвячено вивченню впливу маркетингових технологій, фінансової грамотності, впровадження електронної системи сплати, психологічних механізмів використання молоддю кредитних продуктів. Особлива увага акцентується на розробці конструктивної системи аналізу і формуванні фінансової грамотності, як запоруки матеріального благополуччя i «розумного» використання кредитних продуктів.

Дослідження в цій галузі на теренах України лише набирають обертів. Це нова сфера психологічних інтересів, що наразі перебуває на стадії розробки. Українські психологи в основному зосередили свою увагу на проблемах економічної соціалізації особистості та входження особистості в економічний простір (В. Москаленко, Г. Авер'янова), психологічні особливості розуміння власності (Н. Дембицька), дослідження ставлення до грошей i грошових установок (І. Зубішвілі, В. Комаровська, Т. Миронова, О. Нікітіна, О. Ходакевич), особливостей економічної поведінки особистості (І. Білоконь, В. Верховин, Т. Єфременко, В. Мяленко, О. Паршак) тощо.

Для сучасної молоді гроші стають вагомим фактором у порівнянні людей, володіння грошима зумовлює різну поведінку, яка пов'язана із самоствердженням особистості (Зубіашвілі, 2007). Молодь часто розцінює гроші як єдиний засіб для закріплення свого статусу в суспільстві або сприйняття самого себе, зміни образу «Я». Вступаючи в економічне життя, молодь часто не має необхідних знань і навичок, що може створити серйозні проблеми. Тому в такій ситуації важливою $є$ ефективна економічна освіта, яка формує у молоді адекватну психологічну реакцію на економічні явища, особливо в умовах кризових ситуацій, а від цього залежить успішне майбутнє окремої особистості, країни й світу загалом (Білоконь, 2007).

Аналіз праць зарубіжних і вітчизняних учених про особливості ставлення до грошей особистості юнацького віку засвідчує, що молодь особливо цінує гроші й здебільшого сприймає їх, як благо, як символ престижу та влади. Таке ставлення у поведінковому аспекті призводить до постійно зростаючих і непотрібних витрат. Учені зазначають, що підвищена цінність грошей, заклопотаність грошима, а також підвищена увага до них, характерна як для юнацтва молодшої групи (старшокласники), так і для молоді старшої групи (випускники шкіл, студенти) (Зубіашілі, 2008). Вивчаючи типологію ставлення молоді до грошей, М. Семьонов також виявив, що найбільша частина досліджуваних молодих людей виявляє 
значну грошову заклопотаність, підвищену увагу до грошей і пов'язаними з ними темами, решта старшокласників демонструє грошову розслабленість, знижену увагу до грошей, витіснення, грошове заперечення, марнотратність (при цьому витрачання грошей не приносить терапевтичного ефекту) (Семенов, 2009). Встановлено, що основна відмінність між здобувачами та випускниками закладів вищої освіти полягає в уявленнях про способи заробляння грошей і досягнення життєвого успіху. Проте для школярів провідними рисами досягнення успіху є наполегливість, цілеспрямованість, ініціативність і заповзятливість, а для здобувачів вищої освіти такими рисами є талановитість, здібності, працелюбність (Ходакевич, 2012). О. Щедріна відзначила, що новим в економічній поведінці молоді $є$ підвищення ролі грошової мотивації. Так, зокрема зазначено, що сприйняття себе багатим або бідним впливає на формування професійного вибору особистості. Відсутність грошей у молодих представників бідних сімей спонукає їх обирати професію з більшими заробітками, організовувати комерційну чи виробничу діяльність (Савлук, 2011). За О. Філінковою, вибір економічної діяльності пов'язаний не стільки зі сприйняттям людьми себе багатими чи бідними, скільки 3 ціннісним ставленням до грошей, сприйняттям їх як засобу або мети (Москаленко, 2006).

О. Нікітіна, досліджуючи моральну оцінку грошей особистістю юнацького віку, побудувала ієрархічну модель оцінок грошей. В цій моделі відзначено, що молодь сприймає гроші здебільшого, як засіб для здійснення владного впливу, задоволення широкого спектру потреб і не дуже замислюється над моральним аспектом грошей (Нікітіна, 2010). Лише для людей з шизоїдною та циклоїдною структурою особистісного психотипу властиве однакове ставлення до матеріальних і духовних цінностей (Зубіашвілі, 2008). Отже, зростаюча потреба юнаків і дівчат життєвому самовизначенні суттєво пов'язана 3 фактором матеріальних цінностей, проте одночасно зменшується значущість такого фактору, як духовні цінності.

На думку Ф. Осіна, здобувачі вищої освіти схильні високо оцінювати взаємозв'язок соціального капіталу і грошей. Позитивна оцінка грошей також корелює $з$ оцінкою цінності зв'язків для економії часу. Дослідник відзначає високу схильність ототожнювати гроші та особисті зв'язки. Ті, хто позитивно оцінює гроші, схильний цінувати значимість особистих зв'язків як для матеріального благополуччя, так і для економії часу за рахунок швидкості вирішення питань «по знайомству», що, в свою чергу, сприяє економії грошей. Однак, автор зауважує, що взаємозв'язок час-гроші-друзі не транзитивний, і є частина здобувачів, які позитивно оцінюють зв'язок грошей і соціального капіталу, але негативно оцінюють зв'язок економії часу і соціального капіталу (Габбард \& Глен, 2004; Мазараки, 2004).

Отже, на основі аналізу літератури можна виокремити певні протиріччя у ставленні молоді до грошей: пріоритетність грошей як цінності; нечітке розуміння сутності грошей; розмиті уявлення про способи заробітку грошей; пріоритетність діяльності, пов'язаної із витрачанням грошей; когнітивний дисонанс у свідомості молоді щодо орієнтації на споживання без орієнтацій на високий заробіток; грошова тривожність, негативізм у матеріально незабезпечених представників; віра у власні сили і в те, що доля людини залежить від неї самої та ін. Крім того, можна відзначити значний вплив ставлення здобувачів до грошей на їх професійне та особистісне становлення.

Мета дослідження: емпірично вивчити психологічні особливості сприйняття кредитних продуктів банківських установ здобувачами вищої освіти. Завдання дослідження: 1) визначити типи грошових настанов у здобувачів; 2) вивчити чинники, які впливають на ставлення здобувачів вищої освіти до грошей; 3) проаналізувати обізнаність здобувачів у 
питаннях діяльності банківських установ, поведінки користувачів банківських кредитів і доцільності користування кредитними послугами банків.

\section{Методи дослідження}

Особливо актуальним виявляється експериментальне вивчення психологічних особливостей сприйняття кредитних продуктів здобувачами вищої освіти. Існує багато англомовних методик для визначення типів грошових настанов (В. Рубінштейн, Т. Танг, А. Фернем, Д. Темплер, К. Ямаучі), проте україномовних методик наразі обмаль (Varina \& Shevchenko, 2020). У дослідженні взяли участь 40 здобувачів вищої освіти закладу вищої освіти. Дослідження проводилося впродовж 2019-2020 н. p. на базі Мелітопольського державного педагогічного університету імені Богдана Хмельницького. Було використано методику «Шкала грошових уявлень та поведінки» (Money Beliefand Behaviour Scale) (aвтор А. Фернем), яка вимірює типи грошових настановлень. Ця методика налічує 60 тверджень, що відбивають особистісні уявлення про гроші та поведінку з ними. Текст методики був перекладений М. Сімків (асистентом кафедри психології Львівського національного університету імені І. Франка) українською мовою та відредагований. У процесі перекладу були враховані морфологічні та синтаксичні особливості української мови та особливості української психологічної термінології. Унаслідок цього, формулювання деяких тверджень були змінені. Авторський варіант методики передбачав оцінювання кожного твердження за семибальною шкалою. Проте, для кращого розуміння респондентами процедури оцінювання була використана п'ятибальна шкала: 1 - повністю незгідний; 2 -незгідний; 3 - займаю нейтральну позицію; 4 - згідний; 5 - повністю згідний.

Для вивчення чинників, які впливають на ставлення здобувачів вищої освіти до грошей, було використано анкету О.Г. Ходакевич «Моє ставлення до грошей». Опитувальник «Ставлення до грошей та кредиту здобувачів вищої освіти» (авт. С.В.Шевченко) (Шевченко, 2019). Він містить 18 питань, які стосуються обізнаності здобувачів у питаннях діяльності банківських установ, поведінки користувачів банківських кредитів та доцільності користування кредитними послугами банків.

\section{Результати та дискусії}

Використання методики «Шкала грошових уявлень та поведінки» (А. Фермен, модифікація М.В. Сімків), яка призначена для визначення грошових настанов особистості, дозволило отримати середньогрупові результати за шкалами «грошова одержимість», «влада», «економність» і «неадекватна поведінка з грошима» (табл. 1.)

Таблиия 1.

Результати дослідження грошових уявлень та поведінки здобувачів вищої освіти

\begin{tabular}{|l|c|}
\hline Шкала & Середнє значення \\
\hline Грошова одержимість & 8,06 \\
\hline Влада (сила) & 8,5 \\
\hline Економність & 7,54 \\
\hline Неадекватна поведінка з грошима & 7,54 \\
\hline
\end{tabular}

Як видно 3 табл. 1, усі шкали свідчать про високий рівень прояву зазначених показників, особливо «грошова одержимість» і «влада». Здобувачі вищої освіти постійно відчувають потребу у грошах і готові на все в рамках закону заради їх примноження. 
Постійно хвилюються за своє фінансове становище та часто фантазують про те, що можна придбати за гроші. Вважають, що їх дохід менший, ніж вони заслуговують, і відчувають себе нікчемніше, порівняно з тими, у кого дохід більший. Такі здобувачі думають, що гроші - це єдине, на що можна розраховувати, і вони можуть вирішити всі їх проблеми. На їх думку, скільки б не зекономив, завжди буде мало. Вони намагаються не давати грошей у борг. Результати засвідчили, що для здобувачів вищої освіти гроші - це засіб, за допомогою якого можна впливати на інших людей і досягати власних цілей. Вони можуть використовувати гроші для того, щоб керувати, залякувати і «купувати» людей власною щедрістю.

В ході емпіричного дослідження було вивчено ставлення здобувачів вищої освіти до грошей та оцінки ролі грошей у їх життєдіяльності (анкета О.Г. Ходакевич «Моє ставлення до грошей»). Окрім того, вивчався вплив «зовнішніх» і «внутрішніх» чинників на прояв цих феноменів. Дослідження засвідчило, що більше, ніж половина респондентів (58,5\%), позитивно ставиться до грошей. Решта респондентів ставляться до грошей нейтрально $(28,1 \%)$, негативно (2,9\%) або невизначено (10,5\%) (табл. 2.).

Таблиия 2.

Загальне ставлення здобувачів вищої освіти до грошей

\begin{tabular}{|l|c|}
\hline Загальне ставлення до грошей & Показники у \% \\
\hline Позитивне & 58,5 \\
\hline Нейтральне & 28,1 \\
\hline Негативне & 2,9 \\
\hline Важко сказати & 10,5 \\
\hline
\end{tabular}

Отже, як видно 3 табл. 2 майже половина здобувачів вищої освіти не має до грошей позитивного ставлення, що можна оцінити, на наш погляд, як певну проблему в їх економічній соціалізації. Проаналізуємо оцінку здобувачами функціональної ролі грошей (табл. 3).

Таблиия 3

Оцінка здобувачами вищої освіти функціональної ролі грошей

\begin{tabular}{|c|c|}
\hline Функціональна роль грошей & Показники у \% \\
\hline Гроші як засіб для оплати за товари і послуги & 47,0 \\
\hline Гроші - це свобода & 50,8 \\
\hline Гроші - мірило особистих досягнень та успіху & 30,7 \\
\hline Влада & 16,6 \\
\hline Задоволення & 29,7 \\
\hline
\end{tabular}

Отримані дані (табл. 3) свідчать про те, що відповіді щодо функціональної ролі грошей за їх змістовно-смисловим навантаженням та кількісним проявом можна поділити на три групи. Першу групу утворили відповіді, які відбивають безпосередню функціональну роль грошей - як засобу для оплати за товари і послуги («будь-що, що приймається для оплати за товари і послуги»). Про цю функцію грошей зазначила майже половина респондентів (47,0\%). До другої групи зараховано відповіді респондентів, які стосуються оцінки грошей, як засобу самореалізації та самоствердження, згідно яких гроші оцінюються, як «свобода» $(50,8 \%)$, «мірило особистих досягнень та успіху» $(30,7 \%)$ і «влада» $(16,6 \%)$. Як бачимо, найбільша кількість, а саме половина від загальної кількості респондентів, в процесі функціональної оцінки грошей віддали перевагу «свободі», яка займає, до речі, взагалі перше 
місце в оцінці здобувачами функціональної ролі грошей. Дещо менше респондентів (приблизно одна третина) оцінюють гроші, як засіб особистих досягнень і успіху. Майже третина осіб (29,7\%) здобувачів відзначили таку функціональну роль грошей, як «задоволення». I значно менше осіб, приблизно шоста частина респондентів, розглядають гроші, як засіб для реалізації влади.

Проаналізуємо результати дослідження психологічних особливостей ставлення здобувачів вищої освіти до грошей і кредиту (табл. 4).

Таблиця 4

Психологічні особливості ставлення до грошей і кредиту здобувачів вищої освіти (у \%)

\begin{tabular}{|l|l|l|l|}
\hline $\begin{array}{l}\text { № } \\
\text { 3/п }\end{array}$ & \multicolumn{1}{|c|}{ Питання } & $\begin{array}{l}\text { Taк } \\
\text { \% }\end{array}$ & $\begin{array}{l}\text { Hi } \\
\text { \% }\end{array}$ \\
\hline 1 & Ви користувалися послугами банку? & 90 & 10 \\
\hline 2 & Ви користувалися банківськими кредитами? & 15 & 85 \\
\hline 3 & Ваші родичі чи друзі брали кредити в банку? & 100 & 0 \\
\hline 4 & $\begin{array}{l}\text { Дивився передачі, репортажі, читав статті про те, що є програми і } \\
\text { психологічні тренінги по роботі з проблемними позичальниками. }\end{array}$ & 60 \\
\hline 5 & $\begin{array}{l}\text { Знаю, що деякі позичальники не погашають кредит, тому що не } \\
\text { мають коштів }\end{array}$ & 100 & 0 \\
\hline 6 & $\begin{array}{l}\text { Знаю, що деякі позичальники свідомо не бажають платити, адже є } \\
\text { шахраями }\end{array}$ & 100 & 0 \\
\hline 7 & $\begin{array}{l}\text { Знаю, що деякі позичальники не можуть зупинитися і беруть } \\
\text { кредити,оскільки мають проблеми з розумінням того, яким чином } \\
\text { зможуть заробити і погасити кредит, не бажаючи вводити в оману } \\
\text { співробітників банку, а в надіїщо «погашення кредиту якось вийде } \\
\text { здійснити» }\end{array}$ & 10 \\
\hline 8 & Ви вважаєте таку поведінку психологічною залежністю від кредитів? & 80 & 20 \\
\hline 9 & $\begin{array}{l}\text { Таким людям потрібна допомога в усвідомленні проблеми і навчання } \\
\text { методикам адекватної поведінки щодо кредитів }\end{array}$ & 20 \\
\hline 10 & $\begin{array}{l}\text { Якщо людина розуміє, що має залежність від кредитів, то їй потрібно } \\
\text { звернутися за допомогою до фахівця? }\end{array}$ & 80 & 20 \\
\hline 11 & Кредити не потрібні взагалі & 0 & 100 \\
\hline 12 & $\begin{array}{l}\text { Кредити допомагають у вирішенні деяких проблем і складних } \\
\text { життєвих ситуацій }\end{array}$ & 5 \\
\hline
\end{tabular}

Згідно результатів опитування (табл. 4), послугами банку користувалися 90\% респондентів, але банківськими кредитами користувалися лише $15 \%$. У всіх респондентів родичі чи друзі брали кредити у банку (100\%). 60\% респондентів переглядали передачі, репортажі, читали статті про те, що $є$ програми i психологічні тренінги по роботі 3 проблемними позичальниками. Всі респонденти знаю, що деякі позичальники не погашають кредит тому, що не мають коштів, а також знають, що деякі позичальники свідомо не бажають платити, адже є шахраями. Втім 90\% обізнані у тому, що деякі позичальники не можуть зупинитися і беруть кредити, оскільки мають проблеми з розумінням того, яким чином зможуть заробити і погасити кредит, не бажаючи обманювати співробітників банку, а в надії, що «погашення кредиту якось вийде здійснити». $80 \%$ респондентів вважають таку поведінку психологічною залежністю від кредитів і таким людям потрібна допомога в усвідомленні проблеми і навчання методикам адекватної поведінки щодо до кредитів, а також $\epsilon$ необхідність звернутися по допомогу до фахівця. 95\% здобувачів вважають, що кредити допомагають в рішенні деяких проблем і складних життєвих ситуацій. Здобувачі, 
які користувалися банківськими кредитами, повертали заборгованість вчасно. На питання що таке «аффлюенца» (англ. affluenza) 25\% респондентів відповіли, що не знають про це, 60\% чули, але не можуть сформулювати, що це таке, а 15\% сформулювали, що це психологічні проблеми при користуванні кредитами та їх погашенні.

При виборі фахівця, який може допомогти подолати проблему залежності від кредитів, 15\% обрали юриста, 10\% - лікаря, 50\% - фінансиста і лише 25\% - психолога. При характеристиці кредиту здобувачі використали такі визначення: заборгованість, проблема, тягар, залежність, обмеження.

\section{Висновки}

Узагальнення результатів дослідження дало змогу сформулювати такі висновки.

Ставлення до грошей - це компонент цілісної системи ставлень особистості, що являє собою інтеріоризований досвід взаємодії з грошима та взаємодії з іншими людьми стосовно грошей у специфічній соціокультурній ситуації. Ставлення здобувачів вищої освіти до грошей - важлива складова їх економічної соціалізації, що є складним, багатоаспектним процесом входження в економічну сферу суспільства, зумовленим прагненням до отримання фінансово-економічної незалежності від батьків, початком здійснення трудової діяльності (у поєднанні з навчанням), реалізацією первісних форм майбутньої професійної діяльності, сильною спрямованістю на створення власної сім'ї тощо.

Результати експериментального дослідження визначили «багатовекторність» в оцінці здобувачами вищої освіти функціональності грошей. Переважна кількість здобувачів не оцінюють гроші, як засіб влади, тобто, у більшості респондентів відсутній підхід до грошей, який стосується можливості отримання та демонстрації зверхності щодо інших людей, використання їх, як певного ресурсу для досягнення своїх цілей тощо. На оцінку здобувачами функціональної ролі грошей впливають, швидше за все, особливості юнацького віку, які, з одного боку, відбиваючи значне прагнення отримати свободу (насамперед, свободу від матеріально-економічної залежності від батьків, свободу самостійно будувати своє життя, обирати роботу тощо), отримувати задоволення від життя, а, 3 іншого, ще недостатню орієнтацію на особистісні успіхи, досягнення, а тим більше, владу, що очевидно, може стати значущим у майбутньому. Посилення орієнтації здобувачів вищої освіти на аналіз функціональної ролі грошей, як засобу досягнення особистісних успіхів та досягнень, тобто, подолання певних обмежень в оцінці функціональної ролі грошей, може, на наш погляд, розглядатися, як один із напрямків подальшої роботи з проблеми усвідомлення функціональної ролі грошей (Osadchyi, Varina, Prokofiev, Serdiuk \& Shevchenko, 2020). 3а результатами дослідження було встановлено зв'язок між рівнями адаптивності здобувачів вищої освіти до соціальних реалій та їх ставленням до грошей.

Перспективним, на наш погляд, є подальше дослідження факторів, що впливають на сприйняття здобувачами вищої освіти грошей і кредитних продуктів.

\section{Література}

1. Білоконь, I.В. (2007). Економічні настановлення як складова економічної соціалізації особистості. Максименко С.Д. (Ред.). Актуальні проблеми психології: збірник. наукових праџь Інституту психології ім. Г.С. Костюка АПН України 7(12), 15-19. Київ : «Логос»,

2. Габбард, Р. Глен. (2004). Гроші, фінансова система та економіка, 50-54. Савлук М. \& Олесневич Д. (Ред.). Київ : КНЕУ. 
3. Гроші та кредит. (2011) : підручник. Савлук М. І. (Ред.). Київ : КНЕУ.

4. Зубіашвілі, І.К. (2007). Гроші як фактор економічної соціалізації. Максименко С.Д. (Ред.). Проблеми загальної та педагогічної психологї: збірник наукових пращь Інституту психології ім. Г. С. Костюка АПН України, IX (2), 110-119. Київ : «ГНОЗІС»,

5. Зубіашвілі, І.К. (2008). Соціально-психологічна сутність грошей. Соціальна психологія,. 1(27), 128-141. Київ.

6. Зубіашілі, І.К. (2008). Дослідження особливостей ставлення старшокласників до грошей. Проблеми загальної та педагогічної психології: зб. наук. праџь Інституту психологї̈ ім. Г.С. Костюка АПН України, X (1), 192-204. Київ : Міленіум.

7. Мазараки, А.А., \& Ильин, В.В. (2004). Философия денег. Київ : КНТЭУ

8. Москаленко, В. (2006). Методологічні засади дослідження економічної соціалізації особистості. Проблеми загальної та педагогічної психологї : зб. наук. праць Інституту психології ім. Г. С. Костюка АПН України, 8(1), 250-257. Київ.

9. Нікітіна, О.П. (2010). Дослідження психологічних компонентів ставлення до грошей в юнацькому віці. Вісник ХНПУ ім. Г.С. Сковороди. Психологія, 33, 175-183. Харків : ХНПУ.

10. Семенов, М.Ю. (2009). Психосемантическое исследование понятия «деньги»: гендерный и возрастной аспекты Омский научный вестник. Серия Общество. История. Современность, 3(78), 124-127.

11. Ходакевич, О.Г. (2012). Аналіз основних чинників формування ставлення студентів до грошей. Актуальні проблеми психології: зб. наук. пращьь Інституту психології ім. Г.С. Костюка НАПН Украӥни, 1(34), 348-354. Київ : А.С.К.

12. Шевченко, С.В. (2019). Восприятие денег как отражение социального поведения человека. Психотерапевт и все для его работы, 7.

13. Osadchyi, V.V., Varina, H.B., Prokofiev, E.H., Serdiuk, I., \& Shevchenko, S.V. (2020). Use of AR/VR technologies in the development of future specialists' stress resistance: Experience of STEAM-laboratory and laboratory of psychophysiological research cooperation. Paper presented at the CEUR Workshop Proceedings, 2732, 634-649.

14. Varina, H., \& Shevchenko, S. (2020). The peculiarities of using the computer complex HCpsychotests in the process of psychodiagnosis of the level of development of future specialists' mental capacity. Paper presented at the E3S Web of Conferences, 166. doi:10.1051/e3sconf/202016610025

15. Çera, G., Khan, K.A., Mlouk, A., \& Brabenec, T. (2020). Improving financial capability: The mediating role of financial behaviour. Economic Research - Ekonomska Istrazivanja. doi:10.1080/1331677X.2020.1820362

16. Fan, F., \& Chan, K. (2019). Young adults' perceptions of personal loan commercials. Young Consumers, 20(2). doi:10.1108/YC-10-2018-0854

17. Fogel, J., \& Schneider, M. (2011). Credit card use: Disposable income and employment status. Young Consumers, 12(1), 5-14. doi:10.1108/17473611111114740

18. Kassim, S., \& Hussin, S. R. (2016). Do marketing strategies have significant influence on usage of credit cards? Empirical evidence from malaysia. Pertanika Journal of Social Sciences and Humanities, 24 (November), 179-192.

19. Khan, J., Belk, R.W., \& Craig-Lees, M. (2015). Measuring consumer perceptions of payment mode. Journal of Economic Psychology, 47, 34-49. doi:10.1016/j.joep.2015.01.006 
20. Khan, K.A., \& Akhtar, M.A. (2020). Electronic payment system use: A mediator and a predictor of financial satisfaction. Investment Management and Financial Innovations, 17(3), 246-262. doi:10.21511/imfi.17(3).2020.19

21. Khan, K.A., Akhtar, M.A., \& Tripathi, P.K. (2020). Perceived usefulness of social media in financial decision-making: Differences and similarities. Innovative Marketing, 16(4), 145-154. doi:10.21511/im.16(4).2020.13

22. Larracilla-Salazar, N., Peña-Osorio, I.Y., \& Molchanova, V.S. (2019). Education and financial inclusion. an empirical study in students of higher education. European Journal of Contemporary Education, 8(4), 810-818. doi:10.13187/ejced.2019.4.810

23. Luukkanen, L., \& Uusitalo, O. (2019). Toward financial Capability - Empowering the young. Journal of Consumer Affairs, 53(2), 263-295. doi:10.1111/joca.12186

\section{References}

1. Bilokon, I.V. (2007). Ekonomichni nastanovlennia yak skladova ekonomichnoi sotsializatsii osobystosti [Economic attitudes as a component of economic socialization of the individual]. In S.D. Maksymenko. (Ed). Aktualni problemy psykholohii: zbirnyk naukovyh prats Instytutu psykholohii im. H. S. Kostiuka APN Ukrainy, 7(12), 15-19. Kyiv : «Lohos» [in Ukrainian].

2. Habbard, R. Hlen. (2004). Hroshi, finansova systema ta ekonomika. [Money, financial system and economy], 50-54. In M. Savluk, D. Olesnevych (Ed). Kyiv : KNEU. [in Ukrainian].

3. Hroshi ta kredyt. (2011). [Money and credit]. Pidruchnyk. In M. I. Savluk. (Ed). Kyiv : KNEU. [in Ukrainian].

4. Zubiashvili, I.K. (2007). Hroshi yak faktor ekonomichnoi sotsializatsii [Money as a factor of economic socialization] In S.D. Maksymenko. (Ed). Problemy zahalnoi ta pedahohichnoi psykholohii: zb. nauk. prats Instytutu psykholohii im. H.S. Kostiuka APN Ukrainy. Kyiv : «HNOZIS», IKh (2), 110-119 [in Ukrainian].

5. Zubiashvili, I.K. (2008). Sotsialno-psykholohichna sutnist hroshei [Socio-psychological essence of money]. Sotsialna psykholohiia - Social psychology, 1(27), 128-141 [in Ukrainian].

6. Zubiashili, I.K. (2008). Doslidzhennia osoblyvostei stavlennia starshoklasnykiv do hroshei [Research of features of the relation of senior pupils to money]. Problemy zahalnoi ta pedahohichnoi psykholohii: zb. nauk. prats Instytutu psykholohii im. H.S. Kostiuka APN Ukrainy - Problems zahalnoi ta pedahohichnoi psykholohii: zb. science prats of the Institute of psykholohii them. H.S. Kostyuk APN of Ukraine, X (1), 192-204. Kyiv : Milenium [in Ukrainian].

7. Mazaraki, A.A., \& Ilin, V.V. (2004). Filosofija deneg [Philosophy of money]. Kyiv : KNTEU [in Ukrainian].

8. Moskalenko, V. (2006). Metodolohichni zasady doslidzhennia ekonomichnoi sotsializatsii osobystosti [Methodological bases of research of economic socialization of the person]. Problemy zahalnoi ta pedahohichnoi psykholohii : zb. nauk. prats Instytutu psykholohii im. H.S. Kostiuka APN Ukrainy - Problems of general and pedagogical psychology: collection. Science. Proceedings of the Institute of Psychology. GS Kostyuk, Academy of Pedagogical Sciences of Ukraine, 8(1), 250-257 [in Ukrainian].

9. Nikitina, O.P. (2010). Doslidzhennia psykholohichnykh komponentiv stavlennia do hroshei v yunatskomu vitsi [Research of psychological components of attitude to money in adolescence]. Visnyk KhNPU im. H.S. Skovorody Psykholohiia - Bulletin of KhNPU named after G.S. Skovorody. Psychology, 33, 175-183. Kharkiv : KhNPU [in Ukrainian]. 
10. Semenov, M.Ju. (2009). Psihosemanticheskoe issledovanie ponjatija «den'gi»: gendernyj i vozrastnoj aspekty [Psychosemantic study of the concept of "money": gender and age aspects] Omskij nauchnyj vestnik. Serija Obshhestvo. Istorija. Sovremennost' - Omsk Scientific Bulletin. Society series. Story. Modernity, 3(78), 124-127 [in Russian].

11. Khodakevych, O.H. (2012). Analiz osnovnykh chynnykiv formuvannia stavlennia studentiv do hroshei [Analysis of the main factors shaping the attitude of students to money]. Aktualni problemy psykholohii : zb. nauk. prats Instytutu psykholohii im. H.S. Kostiuka NAPN UkrainyActual problems of psychology: a collection of scientific works of the Institute of Psychology. GS Kostyuk NAPS of Ukraine, 1(34), 348-354. Kyiv : A.S.K [in Ukrainian].

12. Shevchenko, S.V. (2019). Vosprijatie deneg kak otrazhenie social'nogo povedenija cheloveka [Perception of money as a reflection of human social behavior]. Psihoterapevt i vse dlja ego raboty - The psychotherapist and everything for his work, 7 [in Russian].

13. Osadchyi, V.V., Varina, H.B., Prokofiev, E.H., Serdiuk, I., \& Shevchenko, S.V. (2020). Use of AR/VR technologies in the development of future specialists' stress resistance: Experience of STEAM-laboratory and laboratory of psychophysiological research cooperation. Paper presented at the CEUR Workshop Proceedings, 2732, 634-649.

14. Varina, H., \& Shevchenko, S. (2020). The peculiarities of using the computer complex HCpsychotests in the process of psychodiagnosis of the level of development of future specialists' mental capacity. Paper presented at the E3S Web of Conferences, 166. doi:10.1051/e3sconf/202016610025

15. Çera, G., Khan, K. A., Mlouk, A., \& Brabenec, T. (2020). Improving financial capability: The mediating role of financial behaviour. Economic Research - Ekonomska Istrazivanja. doi:10.1080/1331677X.2020.1820362

16. Fan, F., \& Chan, K. (2019). Young adults' perceptions of personal loan commercials. Young Consumers, 20(2). doi:10.1108/YC-10-2018-0854

17. Fogel, J., \& Schneider, M. (2011). Credit card use: Disposable income and employment status. Young Consumers, 12(1), 5-14. doi:10.1108/17473611111114740

18. Kassim, S., \& Hussin, S.R. (2016). Do marketing strategies have significant influence on usage of credit cards? Empirical evidence from malaysia. Pertanika Journal of Social Sciences and Humanities, 24 (November), 179-192.

19. Khan, J., Belk, R.W., \& Craig-Lees, M. (2015). Measuring consumer perceptions of payment mode. Journal of Economic Psychology, 47, 34-49. doi:10.1016/j.joep.2015.01.006

20. Khan, K.A., \& Akhtar, M.A. (2020). Electronic payment system use: A mediator and a predictor of financial satisfaction. Investment Management and Financial Innovations, 17(3), 246-262. doi:10.21511/imfi.17(3).2020.19

21. Khan, K.A., Akhtar, M.A., \& Tripathi, P.K. (2020). Perceived usefulness of social media in financial decision-making: Differences and similarities. Innovative Marketing, 16(4), 145-154. doi:10.21511/im.16(4).2020.13

22. Larracilla-Salazar, N., Peña-Osorio, I.Y., \& Molchanova, V.S. (2019). Education and financial inclusion an empirical study in students of higher education. European Journal of Contemporary Education, 8(4), 810-818. doi:10.13187/ejced.2019.4.810

23. Luukkanen, L., \& Uusitalo, O. (2019). Toward financial Capability - Empowering the young. Journal of Consumer Affairs, 53(2), 263-295. doi:10.1111/joca.12186 


\title{
PSYCHOLOGICAL FEATURES OF PERCEPTION OF CREDIT PRODUCTS BY HIGHER EDUCATORS \\ Svetlana Shevchenko
}

Ph.D in Psychology, Associate Professor, Associate Professor of the Department of Psychology

Melitopol State Pedagogical University named after Bohdan Khmelnytsky

20, Hetman Str., Melitopol, Ukraine, 72300

Svetlanashev1986@gmail.com, https://orcid.org/0000-0001-8281-243X

\author{
Anna Varina \\ Master of Psychology, Senior Lecturer of the Department of Psychology \\ Melitopol State Pedagogical University named after Bohdan Khmelnytsky \\ 20, Hetman Str., Melitopol, Ukraine, 72300 \\ anyavarina22@gmail.com, https://orcid.org/0000-0002-0087-4264
}

\begin{abstract}
The study of the conditionality of a person's perception of money and credit products is becoming an increasingly popular field of research, as evidenced by the latest publications of both Western and Ukrainian scientists. However, most studies examine only certain prerequisites for personal perception of money and credit. The purpose of the study is an empirical study of the psychological features of the perception of credit products of banking institutions by applicants for higher education. Based on the purpose, we have identified the following objectives of the study: determining the types of monetary attitudes of applicants, studying the factors influencing the attitude of higher education to money, determining awareness of applicants activities of banking institutions, the behavior of users of bank loans and the feasibility of using credit services of banks. The following methods have been used: the method "Scale of money ideas and behavior" (Money Beliefand Behavior Scale, author A. Fernham), "My attitude to money" questionnaire (O.G. Khodakevych), "Attitude to money and credit of higher education seekers" questionnaire (author S.V. Shevchenko), and method "Scale of monetary ideas and behavior" (A. Fermen, modification by M.V. Simkov). It is determined that in adolescence a system of basic attitudes to money manifests itself: the degree of adequacy of credit perception increases in relation to a person, at the same time, credit products are evaluated on the basis of people's own ideas, which are sometimes illusory and superficial, and a person's own image of money and credit is less dependable on the assessments of others. At the same time, complicating the process of economic socialization of the younger generation often leads to an unconstructive perception of money and credit: from giving them too high value, the desire to get rich in any way (up to illegal actions) to the complete leveling of their value.
\end{abstract}

Keywords: credit products, money, attitude to money, perception of credits, monetary attitudes, applicants for higher education. 